\title{
11. PETROLOGY AND MINERALOGY OF PLEISTOCENE SEDIMENTS OVERLYING BASEMENT AT THE MOUTH OF THE GULF OF CALIFORNIA, DEEP SEA DRILLING PROJECT LEG 651
}

\author{
P. P. Timofeev, N. V. Renngarten, and M. A. Rateev, \\ Geological Institute of the USSR Academy of Sciences, Moscow, USSR
}

\section{INTRODUCTION}

Four sites were drilled in young crust at the mouth of the Gulf of California during Leg 65 (Fig. 1) in order to study both the oceanic basement and the overlying sediments. The sediments oyerlying basement range in age from Pleistocene to Pliocene, depending on the age of the crust, and vary in thickness from 60 to 154 meters, depending on their age and sedimentation rate. The deepest sediments drilled were found interlayered with basalt at a sub-bottom depth of 315 meters.

In order to determine the petrology and mineralogy of these sediments, about 90 samples were selected for thin section, immersion, and X-ray diffraction studies. In addition, the content and grain-size distribution of the insoluble residues of the sediments were determined on board the Glomar Challenger.

\section{GENERAL SEDIMENT CHARACTERISTICS}

A layer-by-layer correlation of sediments recovered at each site drilled on Leg 65 is not possible because of variations in tectonic structure and sediment-accumulation rate between sites. Since similar sedimentation processes operated throughout the area, however, the sediments recovered at Sites 482 through 485 have many features in common.

In general, the sediments consist of dark gray to greenish gray clay, silty clay, and sandy mud with thin turbidites composed of sandy silt and fine-grained sand interspersed throughout the sections. The turbidites tend to become more common with depth and, in many holes, the sediments interlayered with basalt have been consolidated to mudstone, siltstone, or claystone. The sediments near the top of the section at one site (483) are rich in nannofossils and diatoms. Although the primary texture of the sediments has been strongly disturbed in most cases by drilling or bioturbation, some rocks show fine horizontal laminations in thin section.

Silty and coarser grained material consists of grains of quartz, feldspars, glauconite, mica, chlorite, and aggregates of montmorillonite. In the heavy fraction, which represents $<1 \%$ of the 0.10 to $0.01 \mathrm{~mm}$ fraction, there are (including opaques): zircon, epidote, zoisite, hornblende (common, less frequently barkevite), rutile, garnet, tourmaline, and titanium minerals. The clastic

\footnotetext{
${ }^{1}$ Lewis, B. T. R., Robinson, P., et al., Init. Repts. DSDP, 65: Washington (U.S. Govt. Printing Office).
}

material is terrigenous and redeposited. It was sometimes found admixed with pyroclastic particles of fresh biotite, shards of acidic to basic volcanic glass, and fragments of hornblende, quartz, plagioclase, and monoclinic pyroxene crystals.

The particles in the groundmass are colored brown by colloidal organic matter (sapropel) and include fine coaly detritus and the remains of siliceous and calcareous organisms. Biogenic silica consists most frequently of diatoms and their fragments, more seldom of skeletons of radiolarians and sponge spicules. Fragments of Ethmodiscus shells are recognized among the diatom fragments. Biogenic carbonate is represented primarily by foraminiferal tests, occasionally by coccoliths, and very rarely (in the turbidites) by fragments of mollusk shells and ostracod valves. Foraminiferal tests are frequently poorly preserved-either crushed or partially dissolved.

The bulk of the sediments consists of detrital clays which settled on the seafloor after coming out of suspension. These consist of particles of montmorillonite, illite, chlorite, and sometimes kaolinite. In addition, a certain amount of clay in colloidal suspension with finely dispersed humus(?) was incorporated in the sediments either as a complicated organic-mineral hydrogel or as distinct organic and clay-rich sediments. In the latter case, shapeless clots of finely dispersed mixed-layer montmorillonite were formed with diffuse pale-green outlines. It is interesting to note that this differentiation may have been caused by mud-ingesting organisms which assimilated the organic material and eliminated the clay as coprolites. These were seldom fossilized as they were subject to bioturbation. Nevertheless, clay coprolites are sometimes well preserved (Plate 1, Fig. 1).

In some sandy and silty layers, the clastic material includes redeposited terrigenous bright green glauconitelike granular aggregates. On the basis of X-ray diffraction studies (see below), these aggregates consist of mixed-layer montmorillonite, containing up to $20 \%$ unexpanded illite. This material is the main component in the clay fraction of many sandy and sandy-silt layers, suggesting that a part of glauconite-like aggregates are broken into clay-size fragments during transportation and redeposition.

The sediments are also characterized by the presence of authigenic pyrite, which forms pseudomorphs after plant remains and sometimes replaces diatom remains, fills foraminiferal tests, and forms shapeless aggregates stretching along the plane of lamination. Authigenic py- 


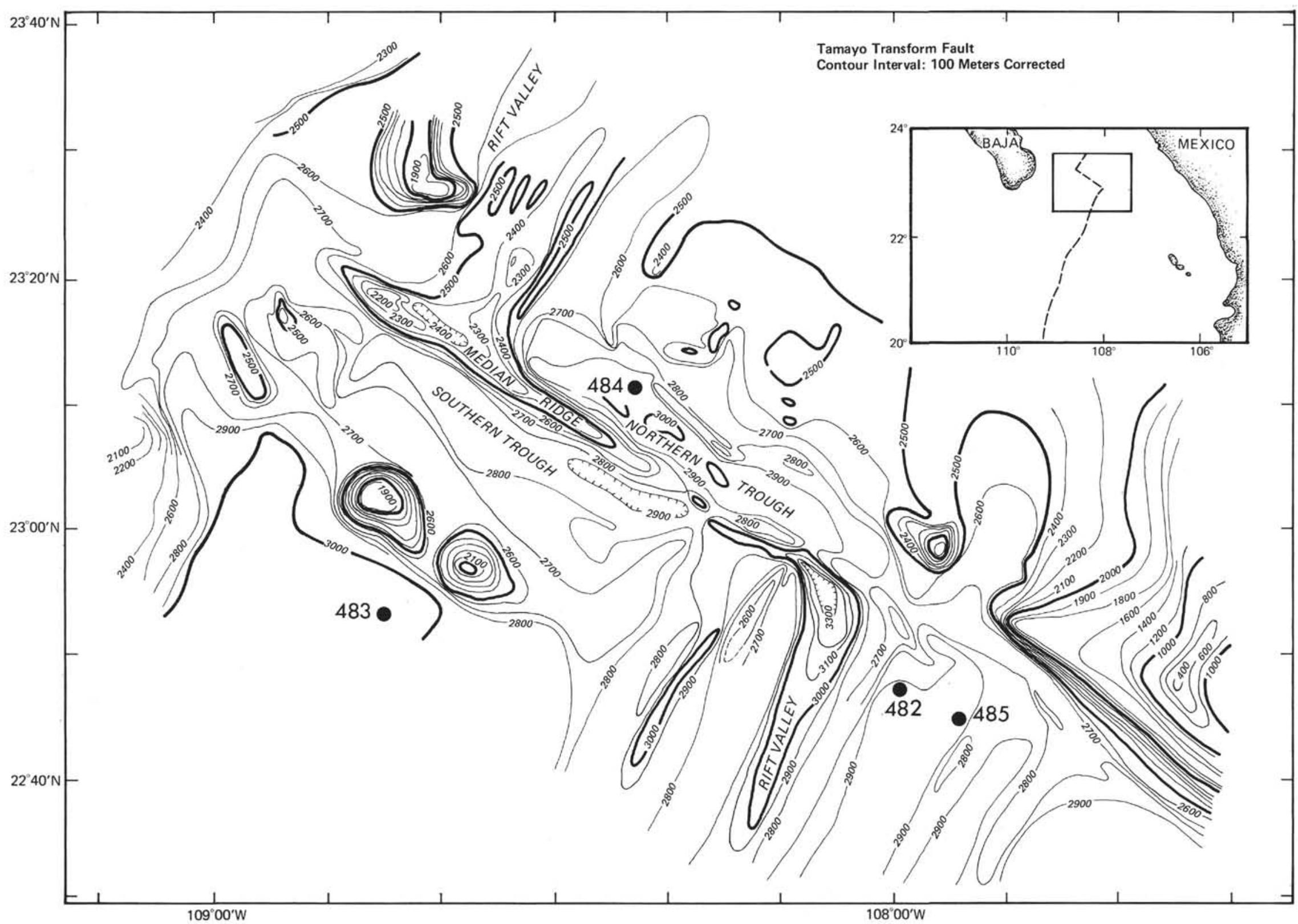

Figure 1. Location of sites drilled on Leg 65. (Contours shown in corrected m.) 
rite is especially abundant near the contact of sediments with basalt. The following pattern was established. In almost all sediments from the upper part of the section, pyrite is associated with ferruginization of plant remains and is represented by an earthy variety, i.e., melnikovite (with dull lustre, almost amorphous). In sediments resting near the contact with basalts and in sediments alternating with basalts, pyrite forms aggregates of well-developed crystals displaying a metallic lustre and striae on faces. Also noted were some cylindrical plant remains composed of both fine-grained aggregates and well-developed crystals of pyrite. One can think of two generations of pyrite here: one associated with ferruginization of plant remains during early diagenesis, the other with iron introduced by hydrothermal activity at a later stage of sediment alteration.

The Pleistocene deposits recovered from the mouth of the Gulf also contain gypsum-a mineral not typical of most oceanic sediments. Gypsum is especially characteristic of the sediments at Sites 482 and 485 . One can observe in each thin section a small number of large crystals or radiating aggregates of gypsum. The following pattern is established: in the lower part of the section, below approximately 101 meters sub-bottom at Site 482 and 127 meters at Site 485 , gypsum forms large $(\sim 0.5 \mathrm{~mm}$ ) radiating aggregates (Plate 1 , Fig. 2$)$. Higher up the section and to the very top, gypsum appears as well-shaped monoclinic crystals (length $\sim 0.3 \mathrm{~mm}$ ) which have fusiform (Plate 1, Fig. 3) or barrel-shaped outlines. Crystals are usually transparent and less commonly turbid, of poikilitic texture. In sediments at Sites 483 and 484 gypsum is, as a rule, identified less commonly and usually occurs as small rosette-like aggregates; only at Site 483 , below 81.5 meters sub-bottom are there large radiating gypsum aggregates. While the large and numerous crystals of gypsum in the deposits examined on Leg 65 may be authigenic, they may result in part from crystal growth accompanying dessication in the laboratory.

\section{SITE 482}

Site 482 is located approximately $12 \mathrm{~km}$ east of the axis of the East Pacific Rise and $15 \mathrm{~km}$ to the south of the Tamayo Fracture Zone. Seven holes were drilled here; a key section was reconstructed from two (Holes 482A and 482B), the total being 230 meters (Fig. 2).

The section is readily subdivided into two units: those overlying the basement (Unit I, which we have further subdivided into three gradational subunits) and those interlayered with basalt.

Unit I extends from the mudline to the top of the basement at a sub-bottom depth of 137.0 meters. The uppermost subunit, $I_{1}$, extends from the mudline to about 30 meters sub-bottom (Cores 1 through 4) in Hole $482 \mathrm{~A}$ and consists of greenish gray silty clays containing red-brown organic matter, scattered nannoplankton remains and tests of foraminifers, and authigenic pyrite. Here and there, ash particles are observed. Remains of siliceous organisms are ubiquitous, though not numer- ous. Large single crystals of authigenic(?) gypsum are common.

Subunit $\mathrm{I}_{2}$ (Hole 482A, Cores 4-5; Hole 482B, Cores 1-6) ranges from 30 to about 100 meters and consists of greenish gray clays with interlayered turbidites of sandy mud and silt. Coccoliths are fairly common throughout the section, and biogenic silica is common high in the section but gradually decreases with depth. Gypsum is also common as well-shaped single crystals.

The most obvious turbidites in Subunit $I_{2}$ are two sandy beds with numerous redeposited grains resembling glauconite in the coarse fraction (Samples 482B-6-5, 97$101 \mathrm{~cm}$; and 482A-5-5, 69-70 cm). The grains are green with rounded contours and radial fissures filled with pale green clay. As noted above, they consist of mixedlayer montmorillonite-illite. The glauconitic grains, together with other sandy and silty particles (quartz, feldspar, hornblende, pyroxene, and basalt fragments) are contained in a matrix of organically mottled calcareous clay along with plant debris (including fragments of coniferous wood) and fragments of large tests of mollusks and ostracod valves.

Subunit $\mathrm{I}_{3}$ extends from 100 to 137 meters sub-bottom (Cores 7-10) in Hole 482B and consists of organically mottled, dark-gray clay with abundant plant detritus and occasional nannoplankton and foraminifer tests. The chambers in many foraminiferal tests are filled with pyrite; in others pyrite only replaces the chamber walls, and the chambers are filled with calcite (sometimes this is a single crystal). It is characteristic that no remains of siliceous organisms were observed here at all. Large radiating aggregates of gypsum are common.

The sediments interlayered in the basement consist for the most part of silty clay.

\section{SITE 483}

Site 483 is located approximately $52 \mathrm{~km}$ west of the East Pacific Rise and about $25 \mathrm{~km}$ east of the base of the continental slope off Baja California. Three holes were drilled here at a water depth of 3070 meters: Holes 483, $483 \mathrm{~B}$, and $483 \mathrm{C}$. Hole 483 was continuously cored to a sub-bottom depth of 204.5 meters, of which the upper 110 meters consists of sediments overlying basement and the remainder consists of interlayered sediments and basalt. Hole 483B was washed to 91.5 meters and was then continuously cored to a depth of 267.0 meters, of which the uppermost 18.5 meters are sediments and the remainder are interlayered sediments and basalts. Hole $483 \mathrm{C}$ was cored only between 38.5 and 48.0 meters and from 86.0 to 114.0 meters.

The composite section is 267 meters thick and can be subdivided into three units (Fig. 2). The uppermost unit (Unit I) ranges from the mud line to the top of the basement at a sub-bottom depth of 110 meters (114 meters on the basis of logs). We have subdivided this unit into three subunits which are similar to those defined by the Leg 65 shipboard party (Site 483 summary, this volume) but which differ slightly in depth. The remaining two units, which we leave unnumbered, consist of inter- 

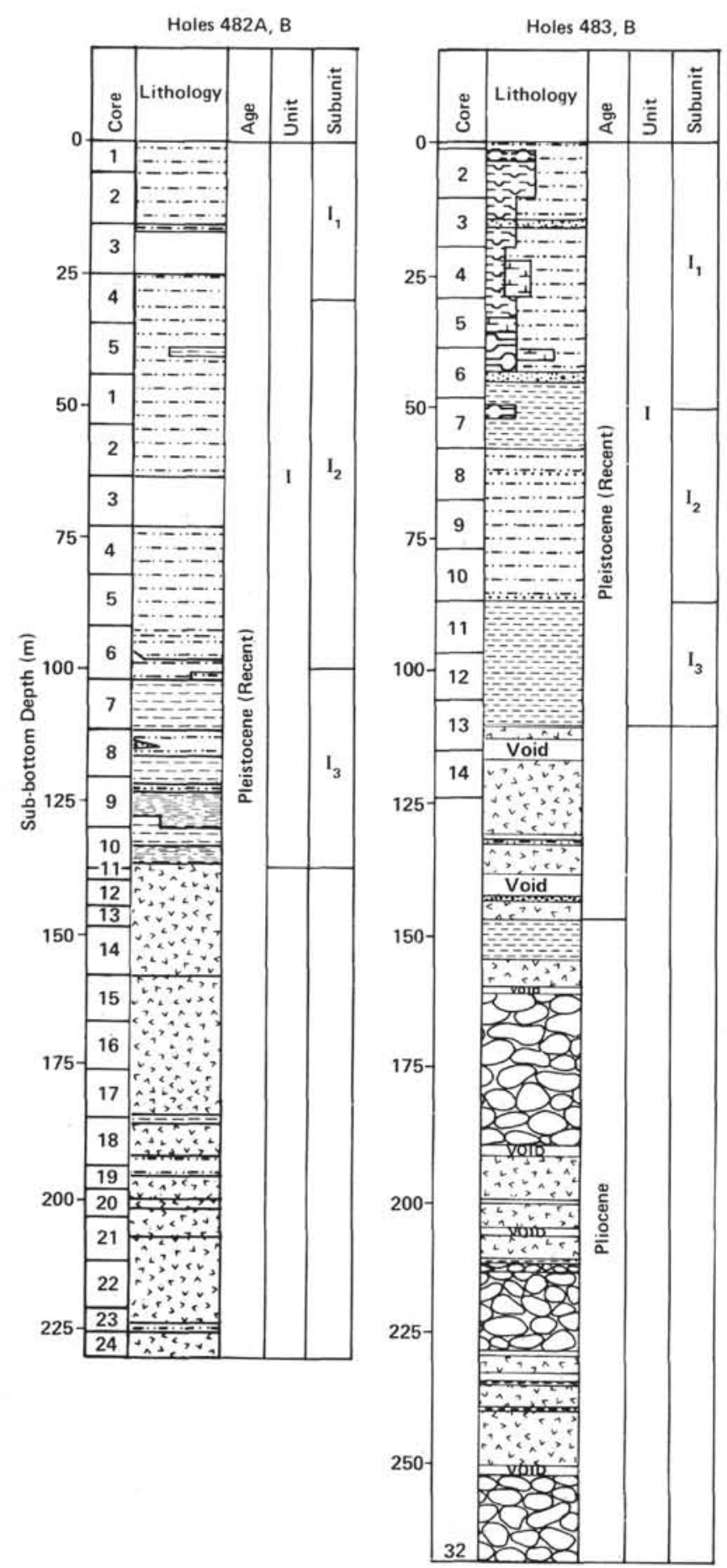

Legend

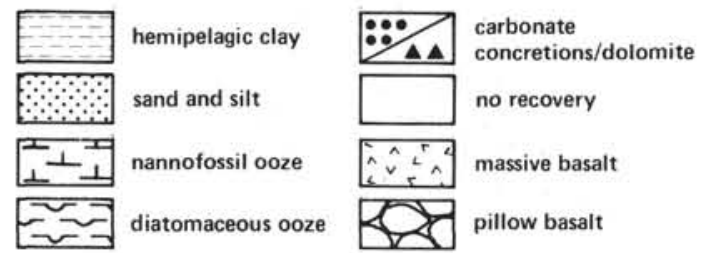

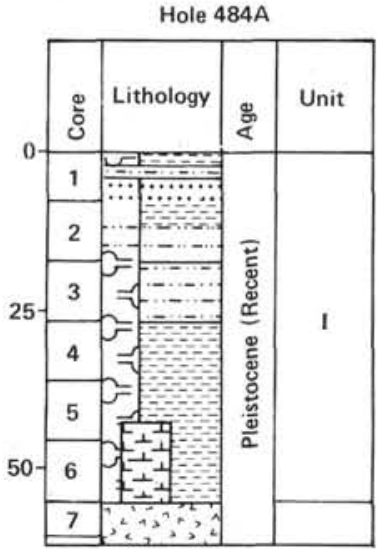

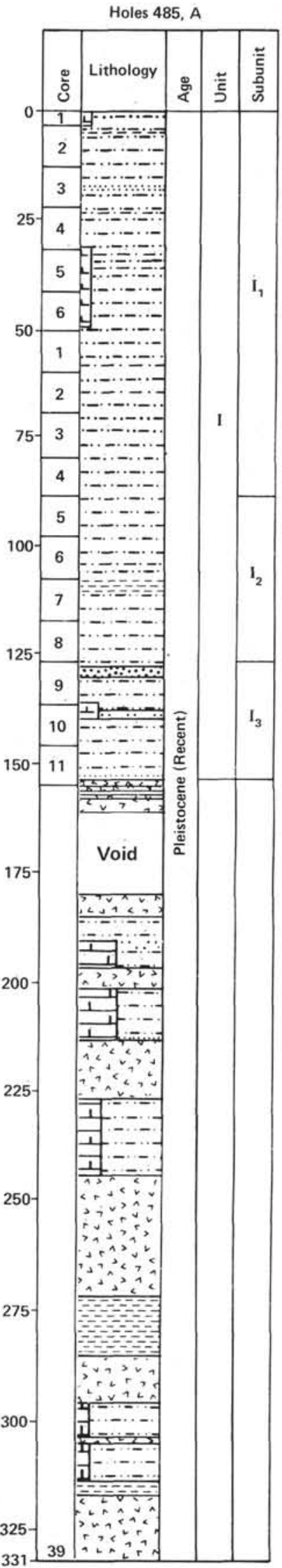

Figure 2. Sediment lithology at Sites 482 through 485 . 
layered sediments and massive basalts from 110 to 169 meters sub-bottom and interlayered sediments, pillow basalts, and massive basalts from 169 to 267 meters.

Subunit $\mathrm{I}_{1}$ extends from the mudline to 48.5 meters sub-bottom (Cores 1-6) and consists of greenish gray diatomaceous silty clay and ooze in which the biogenic silica content decreases with depth. The clays contain fragments of coal and occasional foraminifer tests and are locally mottled with red-brown, colloidal organic matter. Distal turbidites enriched in sand and silt also occur sporadically throughout the subunit. In some intervals there is a small admixture of acid volcanic glass fragments and biotite. Authigenic pyrite is common and small aggregates of gypsum occur locally in the section. Fragments of Ethmodiscus shells are observed among the diatom tests.

Subunit $I_{2}$ extends from 48.5 to 86.5 meters sub-bottom (Cores 7-10) and consists of greenish gray silty clay with rare interbeds of sandy siltstone. In some places (e.g., Section 483-7-5) there is an appreciable admixture of volcanic ash consisting of biotite and fragments of glass, pyroxene, quartz, and plagioclase. The terrigenous component also contains feldspars, mica, chlorite, and aggregates of montmorillonite. The heavy fraction consists predominantly of authigenic pyrite, but also contains grains of hornblende, epidote, zoisite, zircon, garnet, sphene, and euhedral monoclinic pyroxene. Authigenic(?) gypsum is sometimes observed in small aggregates with a poikilitic texture.

The subunit also contains an admixture of biogenic silica which gradually decreases with depth and is composed of diatoms mixed with small amounts of radiolarians and sponge spicules. The carbonate content of the sediments ranges from $20 \%$ to $25 \%$ and consists of poorly preserved foraminifer tests. There are intervals, however, which also contain relic coccoliths. In addition, small calcareous concretions are observed in some silty interbeds. In general, the sediments are strongly bioturbated. Burrows are especially distinct in Cores 7 and 8 . In places where coprolites are abundant, the clay fraction contains a large component of mixed-layer montmorillonite minerals. As in the overlying subunit, plant detritus and organic mottling are present but not abundant.

Subunit $\mathrm{I}_{3}$ ranges from 86.5 to 115.0 meters sub-bottom (Cores 11-13) and consists of dark gray silty clay with rare thin layers containing up to $30 \%$ silt. In places one can observe traces of thin, primary, horizontal lamination, but in most cases the primary layering is not preserved because of intense bioturbation or drilling disturbance. The carbonate content of the sediment is low as a result of the poor preservation of thin-walled tests. Single coccoliths are rare. Coal fragments and colloidal humic matter, on the other hand, are common.

As in Subunit $I_{2}$, the silt-size particles in Subunit $I_{3}$ consist of quartz, feldspars, micas, chlorite, and aggregates of minerals belonging to the montmorillonite group. Pyrite in the form of ball-like grains, solid, irregular aggregates, and pseudomorphs after plant fragments always predominates among the heavy minerals, but grains of hornblende, epidote, zoisite, zircon, garnet, sphene, and monoclinic pyroxene are also present. Small fragments of acid volcanic glass occur sporadically throughout the interval, and the sediments also contain large $(0.30-0.50 \mathrm{~mm})$ radiating aggregates of gypsum.

\section{SITE 484}

Two holes, 484 and $484 \mathrm{~A}$, were drilled on top of a basement high interpreted as a magnetic "diapir" near the north wall of the Tamayo Fracture Zone (Fig. 1). The deeper of the two, Hole $484 \mathrm{~A}$, penetrated 59.5 meters of sediments and 2.5 meters of basalt. Although the shipboard party divided the sediments into two distinct units (Site 484 summary, this volume) we have recognized only one unit.

Unit I ranges from 0 to 59.5 meters sub-bottom (Cores 1-6) and consists largely of diatomaceous clay and clayey diatomaceous ooze with scattered foraminifer tests, coccoliths, and rare ostracod valves. In the upper part of the section, the clays are enriched in biogenic silica (Plate I, Fig. 4), while the lowermost 9 meters consist of silty clay with numerous foraminifer tests and nannoplankton remains. The silt-size particles consist of quartz, feldspars, montmorillonite aggregates, and mica. Ashy particles composed of biotite, acid volcanic glass, hornblende, and pyroxene are also sometimes observed. Gypsum is not characteristic of the section, but small rare aggregate grains (usually with a poikilitic texture) were observed in Core 1, Section 3 and Core 6, Section 2. Coal fragments, authigenic pyrite, and mottling caused by colloidal organic matter are present throughout the section.

\section{SITE 485}

Site 485 is located to the east of Site 482 (Fig. 1). Of the two holes drilled at the site, only Hole $485 \mathrm{~A}$ penetrated through the sediments and into basement.

The sediments at the site can most conveniently be described in terms of those overlying the basement (Unit I) and those interlayered with basalt. It is noteworthy that both the Pleistocene section (which extends into the basement) and the sediments interlayered in basalt are thicker at this site than at any of the others drilled on Leg 65 .

As at the other sites drilled on Leg 65, the sediments overlying basement at Site 485 consist largely of clay and silty clay, but turbidites enriched in sand and silt are more frequent here, and silty sediments clearly predominate over clays. The remains of siliceous organisms are either absent or rare and the carbonate content, attributed mostly to thin-walled foraminifer tests, is low. Coccoliths are only preserved locally. In some intervals, fine-grained diagenetic carbonate is present in appreciable amounts. Ash particles composed of acid volcanic glass fragments, plates of fresh biotite, and grains of amphibole and pyroxene are found throughout the section.

Although the sediments in Unit I display very gradual transitions between layers, we have divided the unit into three subunits. As can be seen from a comparison between Figure 2 and the stratigraphic section presented in the Site 485 summary chapter (this volume), our section is similar to that of the shipboard party except that we 
do not subdivide their Unit I, though we do subdivide Unit II.

The uppermost subunit $\left(\mathrm{I}_{1}\right)$ ranges from 0 to $88.5 \mathrm{me}$ ters sub-bottom (Hole 485, Cores 1-6 and Hole 485A, Cores 1-4) and consists of clay and silty clay with numerous turbidites in the upper part of the section. The remains of diatoms and other siliceous organisms are found throughout the interval but are not abundant. Ash particles and large single crystals of gypsum are also fairly common throughout the section (Plate I, Figs. 5 and 6).

Subunit $\mathrm{I}_{2}$ extends from 88.5 to 126.5 meters (Hole $485 \mathrm{~A}$, Cores 5-8) and consists of clay and silty clay with occasional thin, mottled turbidites containing abundant coal fragments. In the lower part of the subunit (Cores $5-7)$, the clay is mottled with fine-grained calcite within which single coccoliths are preserved. The calcite appears to be caused by the dissolution of biogenic $\mathrm{CaCO}_{3}$ followed by the precipitation of calcite during diagenesis. Thin-walled tests of foraminifers are observed everywhere. Remains of siliceous organisms (diatoms and radiolarians) can occasionally be recognized. Gypsum occurs as large, well-developed crystals.

Subunit $\mathrm{I}_{3}$ ranges from 126.5 to 153.5 meters (Hole 485A, Cores 9-11, Section 3) and is composed of silty clay with numerous turbidites composed of silty sand. The silt and sand-size particles consist of quartz, feldspars, micaceous minerals (including chloritized biotite), clay aggregates, grains of glauconite, and occasional fragments of basalt. The heavy fraction contains pyrite, epidote, zoisite, hornblende, and zircon. The clay fraction of the sediments enriched in silt and sand frequently contains an abundant mixed-layer mineral belonging to the montmorillonite group. Gypsum is present throughout the subunit as large radiating aggregates.

The sediments found interlayered with basalt between 153.5 and 331.0 meters sub-bottom (Cores 11-39) consist mostly of terrigenous clays mixed with silt, but turbidites containing fine sand, fragments of coniferous wood, and colloidal humic matter are also common. The silt- and sand-size particles consist of quartz, feldspars, micaceous minerals, chlorite, and fragments of basalt. The heavy fraction contains abundant authigenic pyrite and barite and sporadic grains of zircon and epidote. The sediments interlayered with basalt differ from the overlying sediments in that they are somewhat more consolidated and contain more pyrite. The pyrite is invariably crystalline (melnikovite is absent) and often occurs in aggregates displaying a compact, finely crystalline nucleus encrusted with larger euhedral crystals.

\section{MINERALOGY OF THE CLAY FRACTION}

In addition to the immersion and thin-section studies discussed above, 56 samples were examined using X-ray diffraction techniques to determine the mineralogy of the clay fraction at each site (Figs. 3, 4, and 5). From this analysis, three clay mineral assemblages were distinguished:

1) The montmorillonite-illite-chlorite assemblage. The minerals in this assemblage are detrital in origin and are particularly abundant in the sediments overlying the basement.

2) An assemblage containing an abundant, mixedlayer montmorillonite-illite mineral which is relatively rich in iron (glauconitic). The assemblage is characteristic of distal turbidites.

3) An assemblage dominated by a strongly expanded, mixed-layer montmorillonite-illite mineral of authigenic origin. This assemblage is typical of silty clays enriched in organic matter.

\section{Montmorillonite-Illite-Chlorite Assemblage}

The terrigenous sediments overlying the basement at Sites 482 through 485 range from about 100 to 150 meters in thickness and are rather uniform, both in terms of lithology and the mineralogy of the clay fraction. The silty clays display a particularly uniform mineralogy composed mostly of redeposited detrital montmorillonite and illite with a small admixture of chlorite and kaolinite. The X-ray characteristics of these minerals are consistent with the standard parameters described by Grimm (1953), Brindly (1951), and Brown (1961). The presence of kaolinite was indicated by the disappearance of the $7.15 \AA$ and $3.57 \AA$ peaks after heating to $550^{\circ} \mathrm{C}$ (Drits and Sakharov, 1976; Gradusov, 1976).

Quantitative estimates of the clay content carried out by the Biscaye method (1964) show only minor variations between sites and with depth at each site. Montmorillonite is a predominant component of the clay fraction everywhere, but it is somewhat more abundant in the western part of the transect (Site 483), where it represents $60 \%$ to $70 \%$ of the sediments. In the southeastern part of the transect at Site 482 it reaches $65 \%$, and at Site 485 it ranges from $40 \%$ to $70 \%$. At Site 484 , in the Tamayo Fracture Zone, the montmorillonite content is $60 \%$.

Illite is the second most abundant component of the clay fraction. It is somewhat less abundant in the western part of the transect (at Site 483 it ranges from $15 \%$ to $40 \%)$ than in the eastern part $(35 \%$ to $55 \%$ in Hole $482 \mathrm{~A}$ and $15 \%$ to $35 \%$ at Site 485$)$. At Site 484 illite represents $15 \%$ to $30 \%$ of the clay fraction.

Chlorite and kaolinite together generally constitute $5 \%$ to $15 \%$ of the clay fraction. Only at Site 484 do these two minerals reach values as high as $20 \%$.

The values discussed above are close to those obtained by Kurnosov et al. (this volume). In the tables presented by Kurnosov, however, the $17 \AA$ minerals are usually $5 \%$ to $10 \%$ more abundant. In addition, these authors did not distinguish kaolinite.

The clay minerals found in the terrigenous deposits overlying the basement are commonly fresh to only slightly altered. This is clearly seen in the illites, which show little evidence of expansion to smectite. Similarly, the chlorite minerals show little alteration other than partial alteration of the brucite layer and a tendency to decompose at relatively low temperatures (about $550^{\circ} \mathrm{C}$ ).

The relative monotony of the clay minerals results from a number of factors. Although the region shows considerable basement relief, all of the sites were drilled 


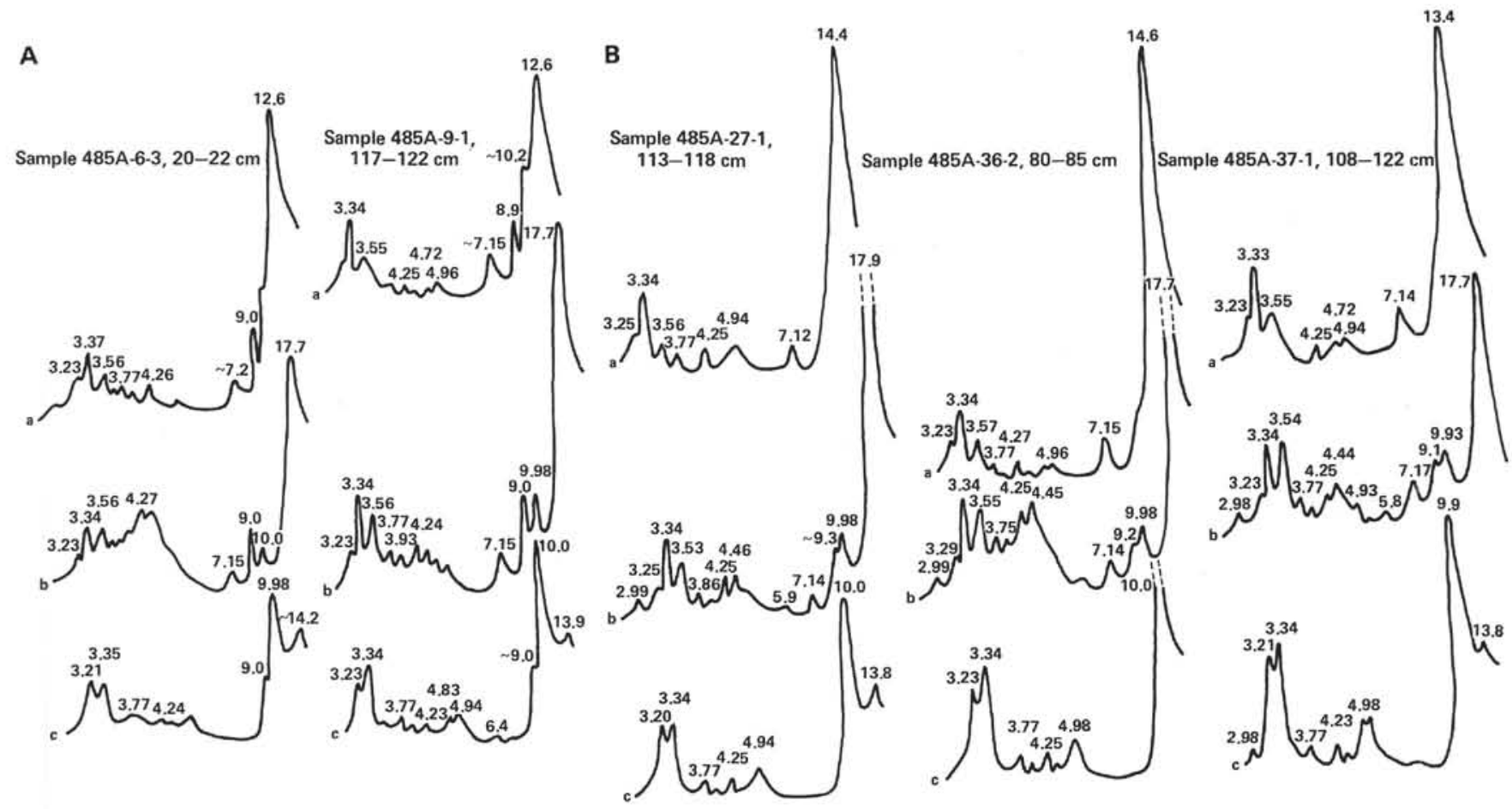

Figure 3. X-ray diffraction diagrams of clay $(<1 \mu \mathrm{m})$ samples from Hole $485 \mathrm{~A}$, showing montmorillonite, illite, and chlorite. A. Sediments overlying basalt. B. Sediments interlayered with basalt. (Curves a, b, and c represent air-dried, glycerine-saturated, and untreated samples, respectively.)

in deep basins fairly far from land. Except for brief periods of turbidity current deposition, in which the clay fraction had a different composition, most of the finely dispersed clay material appears to have been derived from fairly stable source areas and to have been laid down by deep bottom water currents.

The clay minerals found in the sediments interlayered with basalt are basically similar to those in the overlying sediments. Once again, however, our results differ somewhat from those of Kurnosov et al. (this volume). Our analyses, for example, suggest a lower smectite content for this interval $(50-60 \%)$ than that reported by Kurnosov et al. (80-94\%) and a higher illite content (30-40\% vs. $10-25 \%)$.

\section{Glauconitic, Mixed-layer Montmorillonite-Illite Assemblage}

In addition to the detrital clay minerals discussed above, the sediments overlying the basement often contain a glauconitic assemblage in the clay fraction of the turbidites (e.g., Samples 482B-6-5, 27-29 cm, 482D-5-2, 10-14 cm, 483-10-2, 73-77 cm, 485-3-3, 36-40, 485A$11-2,60-75 \mathrm{~cm}$, and $485 \mathrm{~A}-11-3,72-76 \mathrm{~cm}$ ). This material as well as the fine-grained clastic material in the turbidites was derived by erosion and redeposition of the continental slope and shelf deposits off Mexico. The glauconitic material in the sediments displays a mixedlayer montmorillonite-illite structure with iron cations in the octahedral layer and potassium in the spaces between layers. In Sample 482B-6-5, 27-29 cm, the montmorillonite and illite packets are randomly stacked and represent $60 \%$ and $40 \%$ of the structure, respectively. After drying in air, the sample shows a diffraction peak at $d=15.2 \AA$, and after saturation with glycerine, it shows a peak at $d=17.0 \AA$.

\section{Authigenic, Strongly Expanded Mixed-layer Montmorillonite-Illite Assemblage}

A third type of clay mineral assemblage was observed in Sample 483-7-5, 72-75 cm in claystones containing burrows and accumulations of organic matter. In thin section, it is seen as a green authigenic material occurring almost exclusively in the burrows. X-ray diffraction studies show that the predominant mineral displays a mixed-layer, montmorillonite-illite structure in which strongly expanded (smectite) layers predominate over illite $(80 \%$ vs. $20 \%)$. After drying in air, the mineral displays a diffraction peak at $d=13.4 \AA$; and after saturation with glycerine, it shows an asymmetrical peak at $d=18.4 \AA$. Such behavior is consistent both with a mixed-layer structure and with the high dispersion of the mineral. An admixture of detrital illite, chlorite, and kaolinite is also present in the assemblage in small amounts. The presence of a small amount of iron-rich illite in the structure of the authigenic material suggests that a weak initial stage of glauconite formation took place during diagenesis.

\section{CONCLUSIONS}

From the preceding discussion and from data presented elsewhere in this volume, it is evident that the Quaternary sediments overlying basement at the mouth of the Gulf of California are composed largely of dark gray, terrigenous silty clays with occasional turbidites composed of sandy silt and minor clay. The clastic com- 


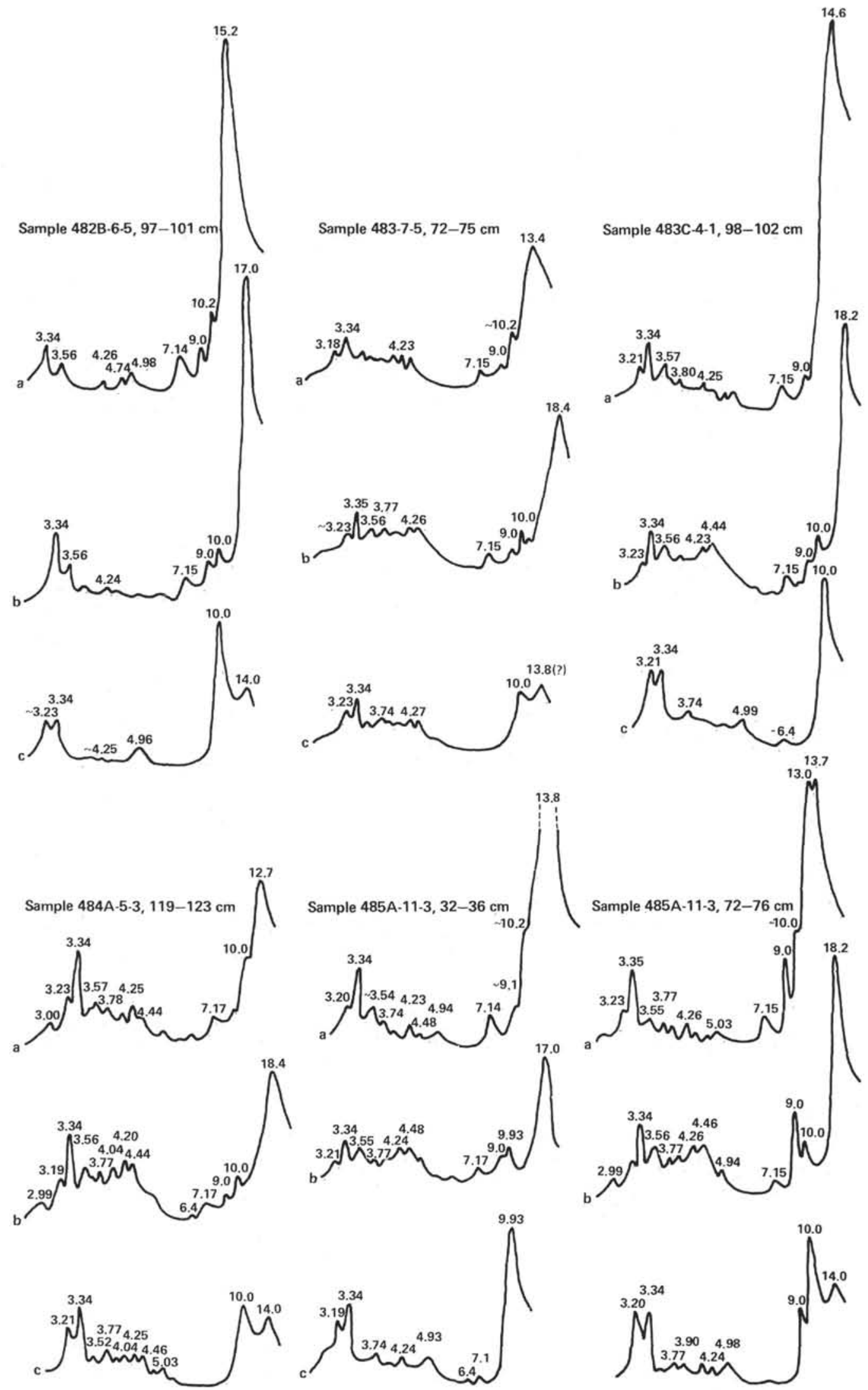

Figure 4. X-ray diffraction diagrams showing mixed-layer minerals in clay samples from Sites 482 through 485. (Curves a, b, and c represent air-dried, glycerine-saturated, and untreated samples, respectively.) 

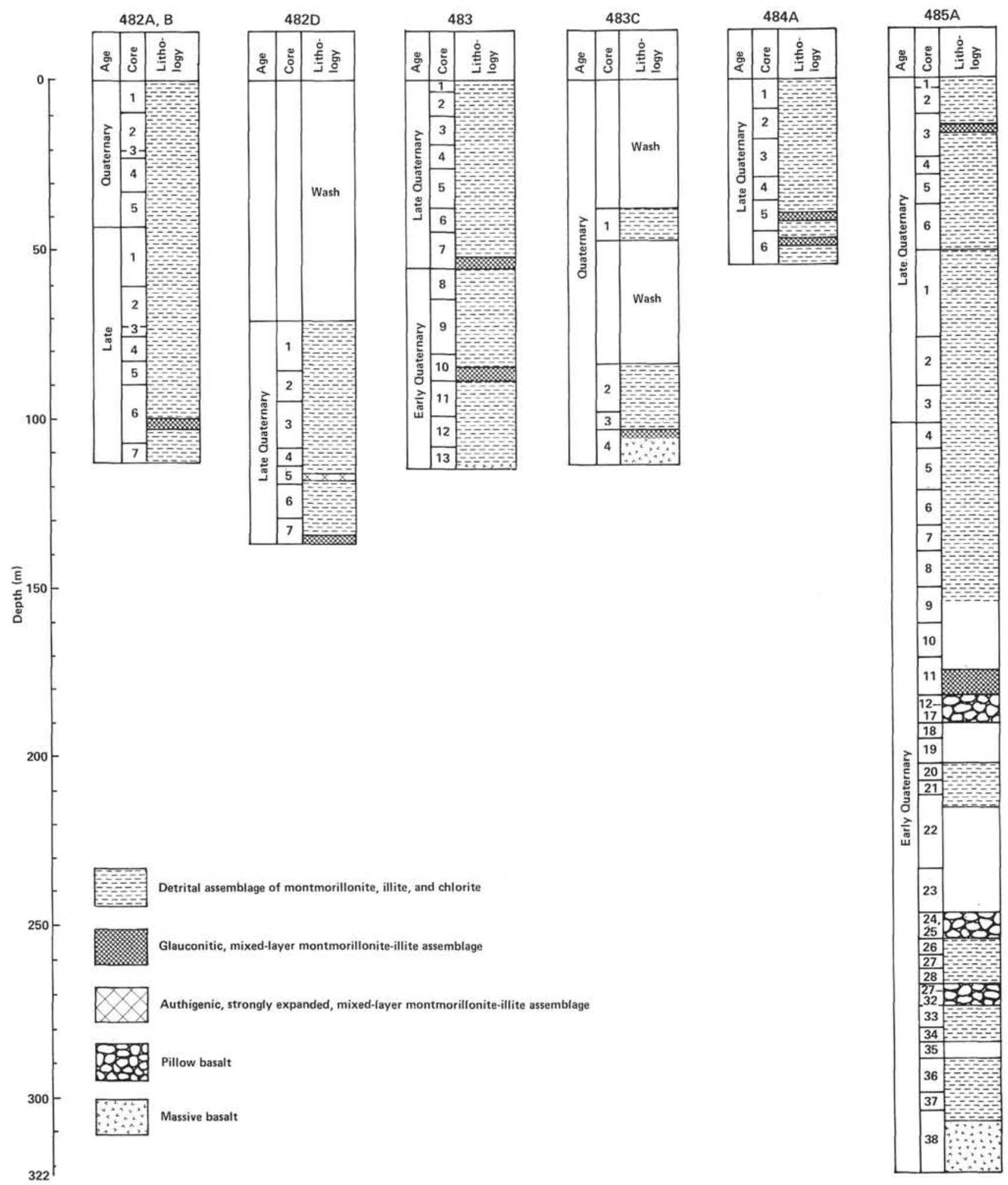

Figure 5. Distribution of clay mineral assemblages in holes drilled during Leg 65 . (NR = no recovery.)

ponent of the sediment is generally polymict, and the mineralogy of the clay component is generally complex throughout the region. The source area of the clastic component of the sediments included pre-existing sediments since the deposits recovered on Leg 65 contain abundant redeposited glauconitic material. The homo- geneity of the sediments indicates that the source of the terrigenous material was relatively stable throughout the Quaternary. The presence of turbidites in the section, however, indicates that the prevailing sedimentation regime was intermittently disrupted by turbidity currents. Judging from their thickness and abundance, the tur- 
bidites at Sites 482 and 485 were derived from a relatively nearby source.

The presence of abundant wood fragments and colloidal organic material in the sediments indicates that the land adjacent to the Gulf supported a thick vegetation which included a coniferous flora, while the remains of such warm-water algae as coccolithophorids suggests that the surface waters in the Gulf were very warm. The poor state of preservation of biogenic carbonate in the sediments may be related to the presence of organic matter since it would have released carbon dioxide during diagenesis, causing the $\mathrm{pH}$ to drop. Similarly, the authigenic pyrite found throughout most of the section may be related to the organic material through reduction. Pyrite near the sediment/basalt contact, on the other hand, may be hydrothermal in origin.

In addition to clastic sediments and organic material, the sediments recovered on Leg 65 often contain small amounts of volcanic ash composed largely of fragments of acidic glass and biotite. This material appears to reflect episodes of andesitic to dacitic volcanism on the mainland.
Finally, the clays recovered from the mouth of the Gulf have a two-fold origin. Most were introduced in suspension and thus reflect the complex mineralogy of the source, but part of the clay fraction consists of authigenic, mixed-layer montmorillonite-illite which formed from a colloidal suspension of organic material and clay.

\section{REFERENCES}

Biscaye, P. E., 1964. Mineralogy and sedimentation of the deep-sea sediment fine fraction in the Atlantic Ocean and adjacent seas and oceans. Geochemistry Technical Report 8. (Department of Geology, Yale University).

Brindly, G. W., 1959. X-ray Identification and Crystal Structures of Clay Minerals: London (Mineralogy Society).

Brown, G., 1961. The X-ray Identification and Crystal Structures of Clay Minerals: London (Mineralogy Society).

Drits, V. A., and Sakharov B. A., 1976. X-ray structural analysis of mixed-layer minerals. Transactions of Gin Acad, Sci., Vol. 295: Moscow (Nauka).

Gradusov, B. P., 1976. Minerals with Mixed-Layer Structure in Soils: Moscow (Nauka).

Grimm, R. E., 1953. Clay Mineralogy: New York (Elsevier). 

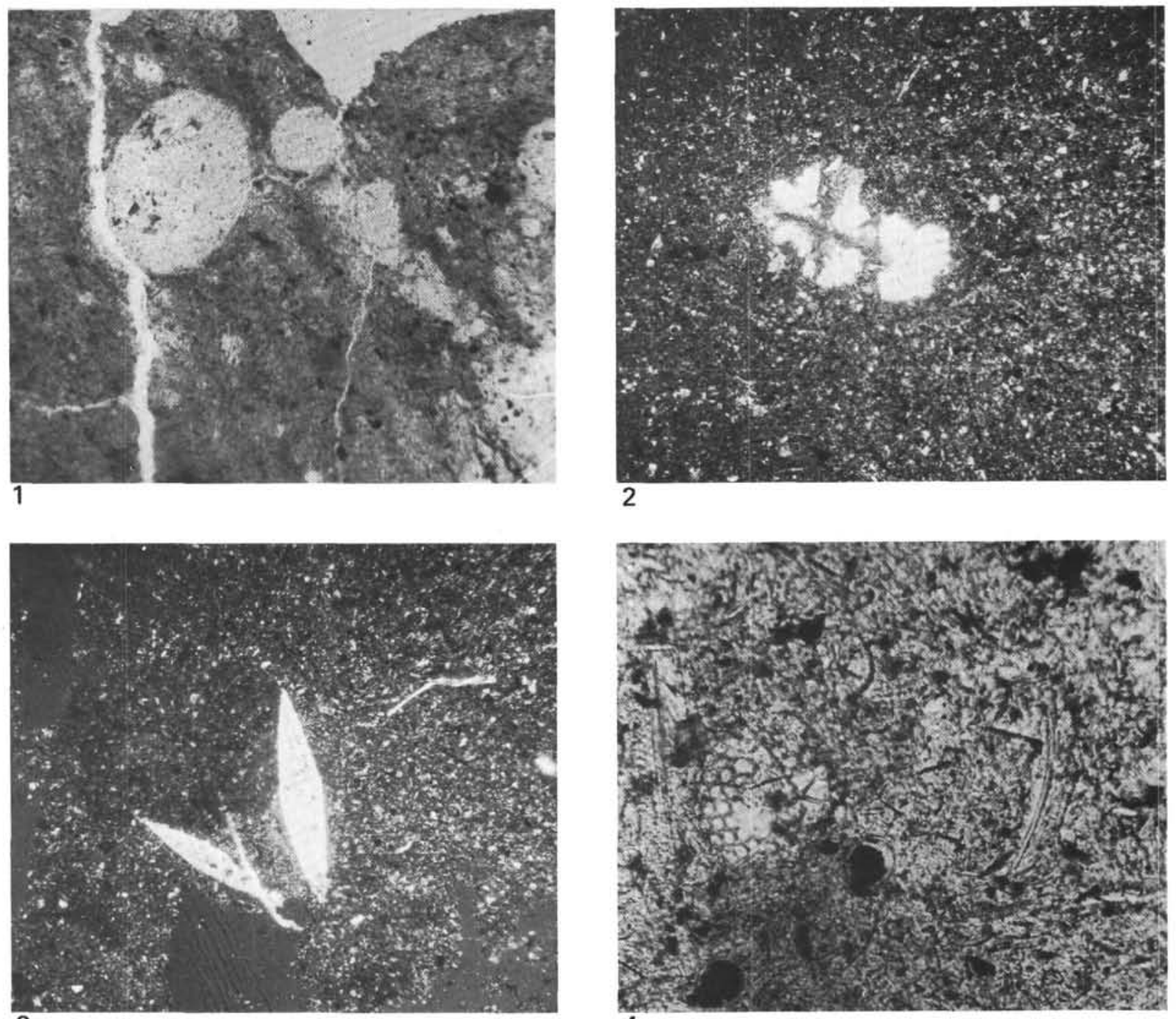

3

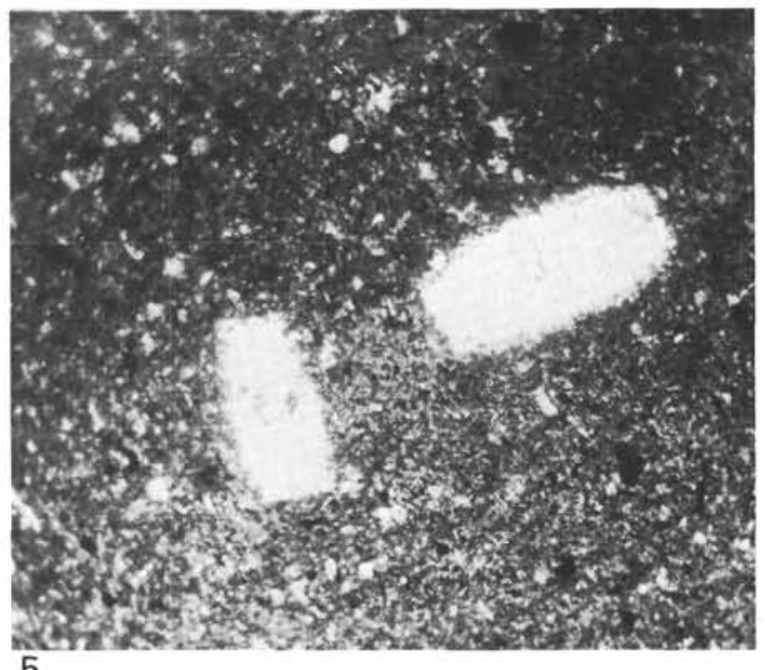

4

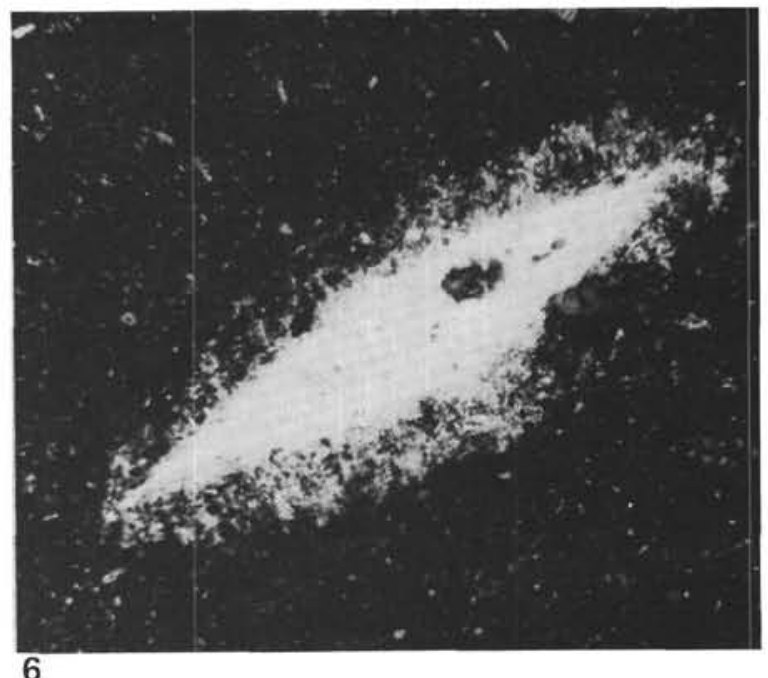

Plate 1. Sediments overlying basement. 1. Clay coprolites, Sample 483-7-5, 72-76 cm, $\times 200.2$. Radiating aggregate of gypsum, Sample 482D-5-2, 10-14 cm, $\times 100$, crossed nicols. 3. Fusiform crystals of gypsum, Sample 482B-4-2, 10-14 cm, $\times 100$, crossed nicols. 4. Biogenic silica in silty clay, Sample 484-2-4, $\times 400$. 5. Barrel-shaped crystals of gypsum, Sample 485-5-3, 100-104 cm, $\times 100$, crossed nicols. 6. Gypsum crystal with poikilitic rim, Sample $485 \mathrm{~A}-3-4,82-87 \mathrm{~cm}, \times 220$, crossed nicols. 